\title{
The Impact of Agricultural Activities on Water Quality: A Case for Collaborative Catchment-Scale Management using Integrated Wireless Sensor Networks
}

\author{
Huma Zia ${ }^{1}$, Nick R Harris ${ }^{1}$, Geoff V Merrett ${ }^{1}$, Mark Rivers ${ }^{2}$, Neil Coles ${ }^{2}$ \\ ${ }^{1}$ Electronics and Computer Science, University of Southampton, United Kingdom \\ ${ }^{2}$ School of Environmental Systems Engineering, University of Western Australia, Australia \\ ${ }^{1}\left\{\right.$ hz2g11,nrh, gvm\} @ ecs.soton.ac.uk, ${ }^{2}$ \{mark.rivers, neil.coles\}@uwa.edu.au
}

\begin{abstract}
The challenge of improving water quality is a growing global concern, typified by the European Commission Water Framework Directive and the United States Clean Water Act. The main drivers of poor water quality are economics, poor water management, agricultural practices and urban development. This paper reviews the extensive role of non-point sources, in particular the outdated agricultural practices, with respect to nutrient and contaminant contributions. Water quality monitoring (WQM) is currently undertaken through a number of data acquisition methods from grab sampling to satellite based remote sensing of water bodies. Based on the surveyed sampling methods and their numerous limitations, it is proposed that wireless sensor networks (WSNs), despite their own limitations, are still very attractive and effective for real-time spatio-temporal data collection for WQM applications. WSNs have been employed for WQM of surface and ground water and catchments, and have been fundamental in advancing the knowledge of contaminants trends through their high resolution observations. However, these applications have yet to explore the implementation and impact of this technology for management and control decisions, to minimize and prevent individual stakeholder's contributions, in an autonomous and dynamic manner. Here, the potential of WSN-controlled agricultural activities and different environmental compartments for integrated water quality management is presented and limitations of WSN in agriculture and WQM are identified. Finally, a case for collaborative networks at catchment scale is proposed for enabling cooperation among individually networked activities/stakeholders (farming activities, water bodies) for integrated water quality monitoring, control and management.
\end{abstract}

Index Terms-wireless sensor networks, agricultural activities, water quality monitoring and management, catchment, collaborative.

\section{INTRODUCTION}

Water is a key natural resource which is vital for the survival of all ecosystems on the planet. However, less than $1 \%$ of the earth's water resources are accessible to humans as fresh water, in the form of either surface or ground water (Krchnak et al., 2002, UNESCO, 2006). Although there is currently sufficient water for essential activities (Blanco et al., 2009) including drinking, irrigation, and domestic and industrial use on a global scale, the spatial distribution of water suggests that, in many cases, it is not available where it is required. Because of the unequal distribution of fresh water resources, billions of people around the globe live in water-stressed and water-limited environments. Therefore it is crucial to preserve water resources although in practice it is continually degraded and depleted owing to inappropriately targeted funding initiatives leading to poor water management, redundant and outdated agricultural practices and urban development (Rosegrant et al., 2002, Verhoeven et al., 2006).

The key issues relating to global freshwater quality problems in the environment and public health are summarized as (FAO, 1996):

1) Non-economic cost of drinking water treatment; 
2) Millions of annual deaths resulting from water-borne diseases;

3) Ecosystem dysfunction and loss of biodiversity;

4) Contamination of marine ecosystems;

5) Contamination of groundwater resources;

6) Depletion of usable water resources;

7) Deterioration of recreational activities.

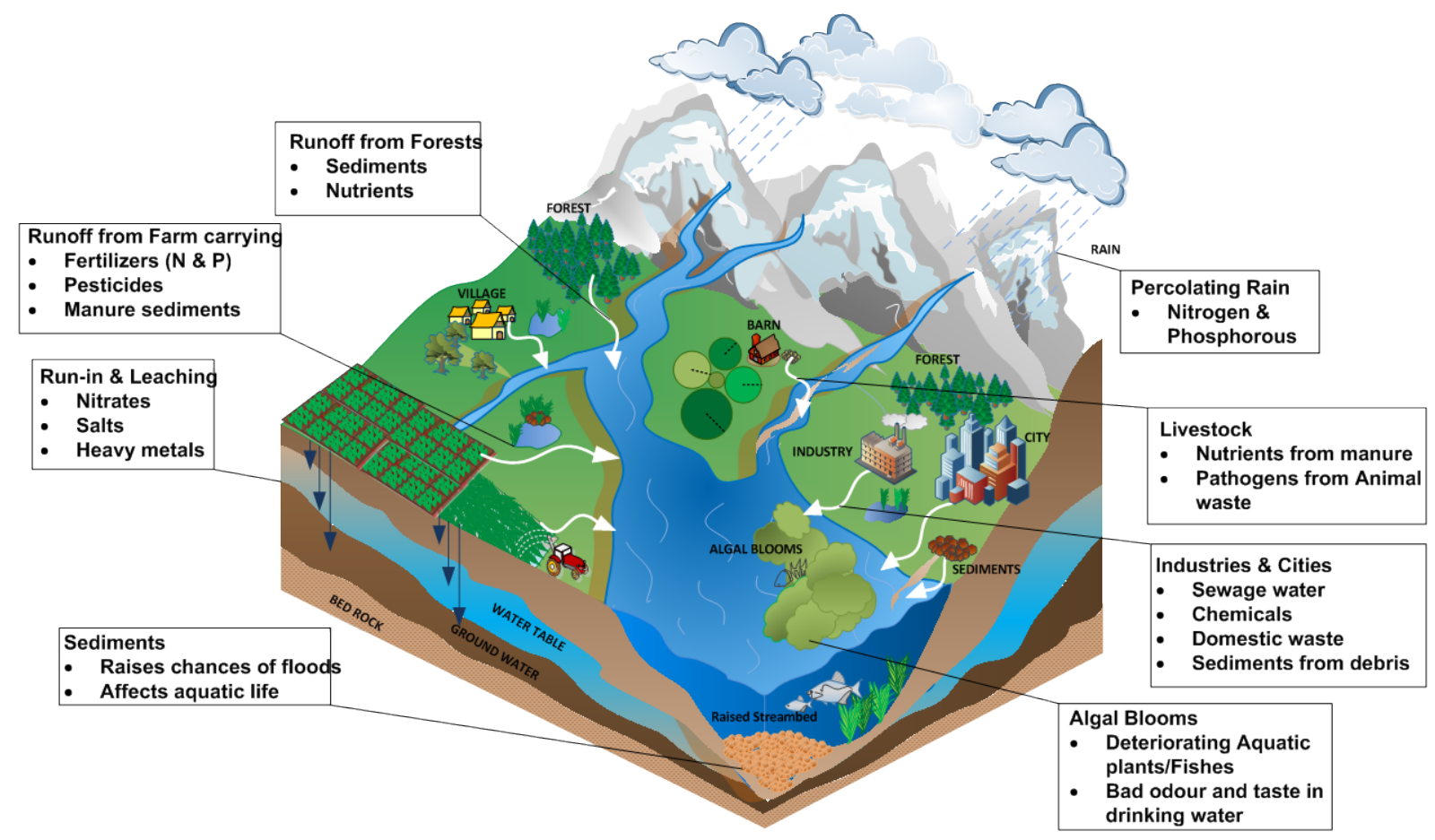

Figure 1: Water Contamination Activities in a Catchment

Problems associated with water quality are commonly attributed to nutrient, chemical and pathogen loadings into an aquatic system as a result of point source and non-point source activities (EPA, 2009). Discharges from point sources are identifiable and come from a single source. Examples include contaminants from sewage plant pipes or industries. On the other hand non-point source fluxes may come from diffused sources/activities with no direct source of entry (FAO, 1996). Examples mainly include agricultural and animal farming or peri-urban activities. A diagrammatic representation of major activities responsible for the degradation of water on a catchment scale owing to point and non-point sources is shown in Figure 1.

While some regulations have been put in place by water quality control organizations in various countries to control toxic and chemical loadings from point source as well as non-point source (Borja et al., 2004, Pollard and Huxham, 1998), they have not been as effective for diffuse non-point sources as for point sources (Heimlich, 2003). In order to prevent and reduce water pollution in the US, the use of best management practices (BMPs) has been proposed by the EPA (Environment Protection Agency) for controlling and managing agricultural practices (UNEP, 1998). However, their effectiveness needs to be assessed using sufficient quantities of long term data. Therefore, it is established that monitoring nutrient and contaminant contributions by the various responsible factors, at key points in a catchment, is vital in assessing and preventing degradation of water quality, as well as informing future regulations (Coles et al., 2009, Hunter and Walton, 2008). In this paper, we review the impacts that different stakeholders have on water resources, and explore how a single stakeholder can have unintended impacts on others in a catchment. Various data acquisition methods from grab samples to satellite images, have been used to estimate and model relationships of land use and water quality degradation in a catchment (Glasgow et al., 2004, Shrestha et al., 2008, Bolstad and Swank, 1997, Tong and Chen, 2002, Lemos et al., 2007). These sampling methods are further reviewed and evaluated in this paper. 
WSNs have been employed for water quality monitoring of surface water (rivers, lakes, and dams), ground water, soil-water and catchments. Water quality parameters such as $\mathrm{pH}$, dissolved oxygen (DO), turbidity, salinity and nitrates have been measured. Preliminary results have been fundamental in advancing the knowledge of contaminants trends, although they were based on spatially constrained observations. Most of these were small scale prototype deployments and were mainly aimed at developing and testing the technology for remote, continuous and real-time data availability. However, these applications have yet to explore the implementation and impact of this technology for management and control decisions, in order to minimize and prevent individual stakeholder's contributions, in an autonomous and dynamic manner. This requires an integration of responsible activities into an autonomous water quality monitoring and management mechanism. Therefore, the potential for including existing WSN-controlled agricultural activities and water bodies, for integrated water quality management, is presented in this review. Later, research challenges in the existing applications of WSNs in this area are identified which, if addressed, would enable possible extension of the existing techniques to an integrated monitoring program.

It is argued in this paper that it is not feasible to have a single monitoring system covering the entire catchment as individual stakeholder's monitoring requirements vary as they undertake different activities. However, this enables a case for collaborative networks in a catchment to be proposed for enabling cooperation among individually networked activities/stakeholders (farming activities, water bodies) for managing water quality.

The structure of this paper is as follows. In section II, the role of agricultural activities on water quality degradation in a catchment is discussed. Section III discusses existing data acquisition methods for WQM, and discuss their limitations, and section IV investigates the ability of WSNs for water quality monitoring and management in a catchment. Section $\mathrm{V}$ discusses the unresolved research challenges that prevent wide adoption of WSNs for monitoring agricultural and water quality parameters and achieving water quality management in a catchment. Finally, section VI presents a case for integrated water quality management using collaboration among individually networked activities in a catchment, while Section VII draws conclusions.

\section{ROLE OF AGRICULTURAL ACTIVITIES ON WATER QUALITY DEGRADATION \& ECOSYSTEM DYSFUNCTION IN A CATCHMENT}

Surface and ground water contamination in a catchment is mainly attributed to outdated farm management practices. These include excessive use of fertilizers for high product yields, traditional irrigation practices, use of pesticides and herbicides and poorly managed animal farming operations (Moss, 2008, EPA, 2009). Other sources include fracking, deforestation, atmospheric deposits by rainfall and untreated sewage waste. However, this paper focuses on the impact of farm management practices on water quality degradation. These practices may result in nutrient, chemical, pathogen and sediment fluxes with main nutrient issues being due to excess phosphorous and nitrogen losses (Carpenter et al., 1998, Hunter and Walton, 2008). Table 1 lists the impacts of catchment scale activities on the quality of surface and ground water resources. For a related representation see (UNESCO, 2006).

\subsection{Surplus fertilizer application}

Fertilizers rich in phosphorous, potassium and nitrogen are added to soil to increase crop yields. However, agronomic nutrient recommendations are often far in excess of environmental levels (Mueller et al., 1996). Therefore, application of nutrients contained in manures and artificial fertilizers often remain in the soil or are leached into the drainage water (Vanlauwe et al., 2001, McKergow et al., 2003). Enrichment of water because of nutrients , termed as eutrophication (Nixon, 1995), can give rise to toxic algal blooms which contaminates drinking water and harms aquatic life (Smith and Schindler, 2009, Min and Jiao, 2002). This acknowledges the need for a mechanism to monitor and assess nutrient inputs to crops, its uptake by crops and losses through runoffs and leaching from farms. 
Table 1: List of catchment-scale activities and their impact on hydrology and ecosystem

\begin{tabular}{|c|c|c|c|c|c|c|}
\hline \multirow{2}{*}{\multicolumn{2}{|c|}{$\begin{array}{l}\text { RESPONSIBLE } \\
\text { ACTIVITIES }\end{array}$}} & \multirow{2}{*}{$\begin{array}{l}\text { CONTAM } \\
\text { INANTS }\end{array}$} & \multirow{2}{*}{$\begin{array}{l}\text { CONSTITUENT } \\
\mathrm{S}\end{array}$} & \multicolumn{3}{|c|}{ IMPACT } \\
\hline & & & & SURFACE & GROUND & ANY OTHER \\
\hline \multirow[t]{5}{*}{$\begin{array}{l}\text { Runoff from } \\
\text { excess } \\
\text { Irrigation, } \\
\text { rain and storm } \\
\text { water }\end{array}$} & $\begin{array}{l}\text { Fertilizers } \\
\text { Manure } \\
\text { Fertigation }\end{array}$ & Nutrients & $\begin{array}{l}\text { Phosphorous, } \\
\text { Nitrogen, } \\
\text { Ammonia, } \\
\text { Dissolved } \\
\text { Oxygen, Chloride }\end{array}$ & $\begin{array}{l}\text { transport of } \\
\text { nutrients, especially } \\
\text { phosphorous \& } \\
\text { nitrogen, leads to } \\
\text { eutrophication, } \\
\text { depletion of } \\
\text { oxygen, foul smell } \\
\text { and odour }\end{array}$ & $\begin{array}{l}\text { Leaching of } \\
\text { nutrients into } \\
\text { ground water } \\
\text { especially } \\
\text { nitrogen } \\
\text { results in } \\
\text { salinity. }\end{array}$ & $\begin{array}{l}\text { Deteriorating } \\
\text { aquatic life, } \\
\text { threat to human } \\
\text { health, } \\
\text { degradation of } \\
\text { drinking water } \\
\text { quality, soil } \\
\text { acidity } \\
\end{array}$ \\
\hline & $\begin{array}{l}\text { Animal } \\
\text { Farming } \\
\text { Operation, } \\
\text { Wildlife } \\
\text { Manure }\end{array}$ & pathogens & $\begin{array}{l}\text { Bacteria, virus, } \\
\text { heavy metals, } \\
\text { cryptosporidium, } \\
\text { Giardia lamblia, } \\
\text { Legionella }\end{array}$ & $\begin{array}{l}\text { Runoff carrying } \\
\text { animal faeces and } \\
\text { urine containing } \\
\text { pathogens and } \\
\text { metals into aquatic } \\
\text { system }\end{array}$ & $\begin{array}{l}\text { Leaching of } \\
\text { nitrogen and } \\
\text { metals }\end{array}$ & $\begin{array}{l}\text { Infectious } \\
\text { diseases in } \\
\text { humans, }\end{array}$ \\
\hline & $\begin{array}{l}\text { Crop } \\
\text { Spraying; } \\
\text { Weed \& Pest } \\
\text { Management }\end{array}$ & $\begin{array}{l}\text { Insecticides } \\
\text { Herbicides } \\
\text { Fungicides } \\
\text { rodenticide }\end{array}$ & $\begin{array}{l}\text { Aldrin, Atrazine, } \\
\text { Chlordane, DDT, } \\
\text { 24DT Dieldrin, } \\
\text { Endrin, Lindane, } \\
\text { Simazine, etc. }\end{array}$ & $\begin{array}{l}\text { Chemical loading in } \\
\text { surface water } \\
\text { affects aquatic life } \\
\text { including poor fish } \\
\text { health, cancers and } \\
\text { tumours in fish \& } \\
\text { amphibians }\end{array}$ & & $\begin{array}{l}\text { Oncological, } \\
\text { pulmonary and } \\
\text { haematological } \\
\text { morbidity in } \\
\text { humans, inborn } \\
\text { deformities, } \\
\text { immune system } \\
\text { deficiency }\end{array}$ \\
\hline & $\begin{array}{l}\text { Cultivation/till } \\
\text { age } \\
\text { Deforestation }\end{array}$ & Sediments & $\begin{array}{l}\text { TSS(Total } \\
\text { Suspended solids), } \\
\text { TDS(Total } \\
\text { Dissolved Solids), } \\
\text { Turbidity. }\end{array}$ & $\begin{array}{l}\text { Cloudiness of } \\
\text { water, siltation of } \\
\text { stream/river bed, } \\
\text { Loss of spawning } \\
\text { ground for fish, } \\
\text { Decreased } \\
\text { penetration of light, } \\
\text { Carries } \\
\text { phosphorous }\end{array}$ & $\begin{array}{l}\text { Deforestation } \\
\text { leads to } \\
\text { increased } \\
\text { surface runoff } \\
\text { and decreased } \\
\text { groundwater } \\
\text { recharge. }\end{array}$ & $\begin{array}{l}\text { Increased costs } \\
\text { on treatment of } \\
\text { water, sediment- } \\
\text { bound nutrients, } \\
\text { disruption and } \\
\text { change in } \\
\text { hydrologic } \\
\text { regime, public } \\
\text { health issues } \\
\end{array}$ \\
\hline & $\begin{array}{l}\text { Excess } \\
\text { Irrigation } \\
\text { Rainfall \& } \\
\text { poor water } \\
\text { management }\end{array}$ & $\begin{array}{l}\text { Salts, } \\
\text { nutrients }\end{array}$ & $\begin{array}{l}\text { Cl (Chloride), } \\
\text { Ca (Calcium), } \\
\text { Mg (Magnesium) }\end{array}$ & $\begin{array}{l}\text { Salinization of } \\
\text { drinking water } \\
\text { resources; } \\
\text { Waterlogging; } \\
\text { Soil salinisation }\end{array}$ & $\begin{array}{l}\text { Enrichment of } \\
\text { groundwater } \\
\text { with salts; } \\
\text { Rising or } \\
\text { perched } \\
\text { watertables, }\end{array}$ & $\begin{array}{l}\text { Affecting crop } \\
\text { yields, } \\
\text { destroying soil } \\
\text { quality }\end{array}$ \\
\hline \multirow[t]{2}{*}{$\begin{array}{l}\text { Untreated } \\
\text { Municipal } \\
\text { Waste }\end{array}$} & $\begin{array}{l}\text { Disposal of } \\
\text { Sewage sludge }\end{array}$ & Pathogens & $\begin{array}{l}\text { Bacteria, virus, } \\
\text { heavy metals } \\
\text { cryptosporidium, } \\
\text { Giardia } \\
\text { lamblia/floridae, } \\
\text { Legionella }\end{array}$ & $\begin{array}{l}\text { Degrades drinking } \\
\text { water quality }\end{array}$ & $\begin{array}{l}\text { Leaching of } \\
\text { nitrogen and } \\
\text { metals }\end{array}$ & $\begin{array}{l}\text { Infectious } \\
\text { diseases in } \\
\text { humans }\end{array}$ \\
\hline & $\begin{array}{l}\text { Domestic } \\
\text { waste }\end{array}$ & $\begin{array}{l}\text { Organic } \\
\text { matter }\end{array}$ & $\begin{array}{l}\text { BOD (Biological } \\
\text { Oxygen Demand), } \\
\text { DOC (Dissolved } \\
\text { Organic Carbon), } \\
\text { DO (Dissolved } \\
\text { Oxygen) }\end{array}$ & $\begin{array}{l}\text { Depletion of } \\
\text { oxygen affecting } \\
\text { aquatic life }\end{array}$ & & \\
\hline Aquaculture & $\begin{array}{l}\text { Pesticides } \\
\text { Faeces }\end{array}$ & $\begin{array}{l}\text { Nutrients } \\
\text { pathogens }\end{array}$ & $\begin{array}{l}\text { Phosphorous, } \\
\text { Nitrogen, } \\
\text { Ammonia, } \\
\text { Dissolved } \\
\text { Oxygen, Chloride, } \\
\text { Bacteria, } \\
\text { virus, heavy } \\
\text { metals }\end{array}$ & $\begin{array}{l}\text { Through feed and } \\
\text { faeces nutrients and } \\
\text { pesticides reach } \\
\text { surface water } \\
\text { leading to } \\
\text { eutrophication }\end{array}$ & & \\
\hline Livestock & $\begin{array}{l}\text { Animal waste } \\
\text { in Grazing } \\
\text { pastures reach } \\
\text { aquatic system }\end{array}$ & $\begin{array}{l}\text { Pathogens } \\
\text { chemicals }\end{array}$ & $\begin{array}{l}\text { Bacteria, virus, } \\
\text { heavy metals }\end{array}$ & $\begin{array}{l}\text { Degrades drinking } \\
\text { water quality }\end{array}$ & $\begin{array}{l}\text { Potential } \\
\text { leaching of } \\
\text { nitrogen, } \\
\text { metals to GW }\end{array}$ & $\begin{array}{l}\text { Affects human } \\
\text { health. }\end{array}$ \\
\hline
\end{tabular}




\subsection{Poor water management}

Irrigation techniques such as surface flooding, localized drip and subsurface irrigation might be efficient in some ways but they can lead to various problems. Under-irrigation, in the case of drip irrigation, can lead to salt buildup on the soil surface and can damage crops. Over-irrigation, in the case of surface irrigation, may not only trigger nutrient/chemical runoff, but can also cause perched water tables resulting in soil salinity problems (McKergow et al., 2003). Furthermore due to scarce water resources, low quality water is being increasingly used for irrigation, which is rich in nutrients and salts (Pereira et al., 2002). This increases the risk of salt accumulation in the root zone and consequent long term damage to crop production and soil fertility(Pitman and Läuchli, 2004, Tedeschi and Dell'Aquila, 2005). This acknowledges the need for an intelligent water management methodology to avoid wastage of water and allow its reutilization.

\subsection{Inadequately managed animal farming operations}

Manure run-off due to rainfall or poorly managed animal farming operations may carry pathogens like bacteria and viruses to water bodies, affecting water quality for both aquatic life and humans (Lipp et al., 2001, Ferguson et al., 2003). Pathogenic micro-organisms are responsible for causing infectious diseases in humans and, are a major cause of decline and destruction of coral reefs worldwide (Bellwood et al., 2004, EPA, 2012). In order to maintain and improve animal health within animal feeding operations (AFO) facilities and to prevent any pathogen and chemical fluxes through fecal discharges from them, it is very important to continuously monitor and control the local environment.

\subsection{Use of pesticides and herbicides}

Pesticide and herbicide applications on crops contribute to chemical deposits in soil, which are carried through runoff and leaching into rivers, lakes and groundwater (Cerejeira et al., 2003, Guzzella et al., 2006). Antibiotics are fed to livestock as growth enhancers, and manure containing these pharmaceuticals is spread on land, from where it leaches into ground water and reservoirs (Daughton, 2004, Reynolds, 2003).

This validates a need for, i) monitoring microclimate of crops to prevent onset of moulds and other diseases, and ii) a mechanism to control chemical laden water into or out of a farm preventing contamination of its own or other's farm or water bodies.

\section{EXISTING WATER QUALITY DATA ACQUISITION METHODS}

This chapter focuses on the major sampling methods which have been used to acquire water quality data to assess surface (rivers, lakes, dams) and ground water (reservoirs, aquifers) bodies. Also, this information has been used to model the relationship between land use and water quality degradation in a catchment (Glasgow et al., 2004, Lemos et al., 2007, Shrestha et al., 2008). This chapter briefly discusses grab sampling, in-situ sampling using data loggers, and remote sensing using satellite imaging, while it focuses mainly on the use of WSNs. This chapter discusses the suitability of WSNs for water quality monitoring and argues how it overcomes the limitations of the other methods.

For decades, field measurements for water quality evaluation have depended upon costly time- and labourintensive on-site sampling and data collection. Water samples are collected from the field and are then analysed in laboratories. This not only give limited point measurements but also become an expensive method for remote sites (Glasgow et al., 2004). Additionally, transportation of samples may disturb their chemical properties(EPA, PacifiCorp, 2002). As data utility is affected in grab sampling by extended holding times before analysis, monitoring programs have shifted towards continuous measurements using in-situ sensors(Lemos et al., 2007) Initially data loggers were used for in-situ monitoring; however they were limited by not providing data in real time as sites had to be visited to retrieve data. The expense of data loggers, infield reliability, calibration requirements and the need to extract data from them individually, prevent them from being used for a dense and long term deployment of sensors.

Alternatively, remote sensing using optical and thermal sensors on aircrafts and satellites can be used to monitor water quality parameters like turbidity, chlorophyll, chemicals, nutrients and temperature (Glasgow et al., 2004, Webster and Grossman, 2003). High resolution remotely sensed data is correlated by empirical or analytical 
models to a water quality parameter (Ritchie et al., 2003). Examples include a modelling approach to estimate phytoplankton in a shallow lake using satellite imagery with sparsely collected ground reference data, which demonstrates temporal stability (Tyler et al., 2006, Matthews et al., 2010). However, this is an expensive solution and its application is limited to regions covered by the satellites. Also, data sampling frequency may be insufficient and data may not be available in real time (Basha and Rus, 2007).

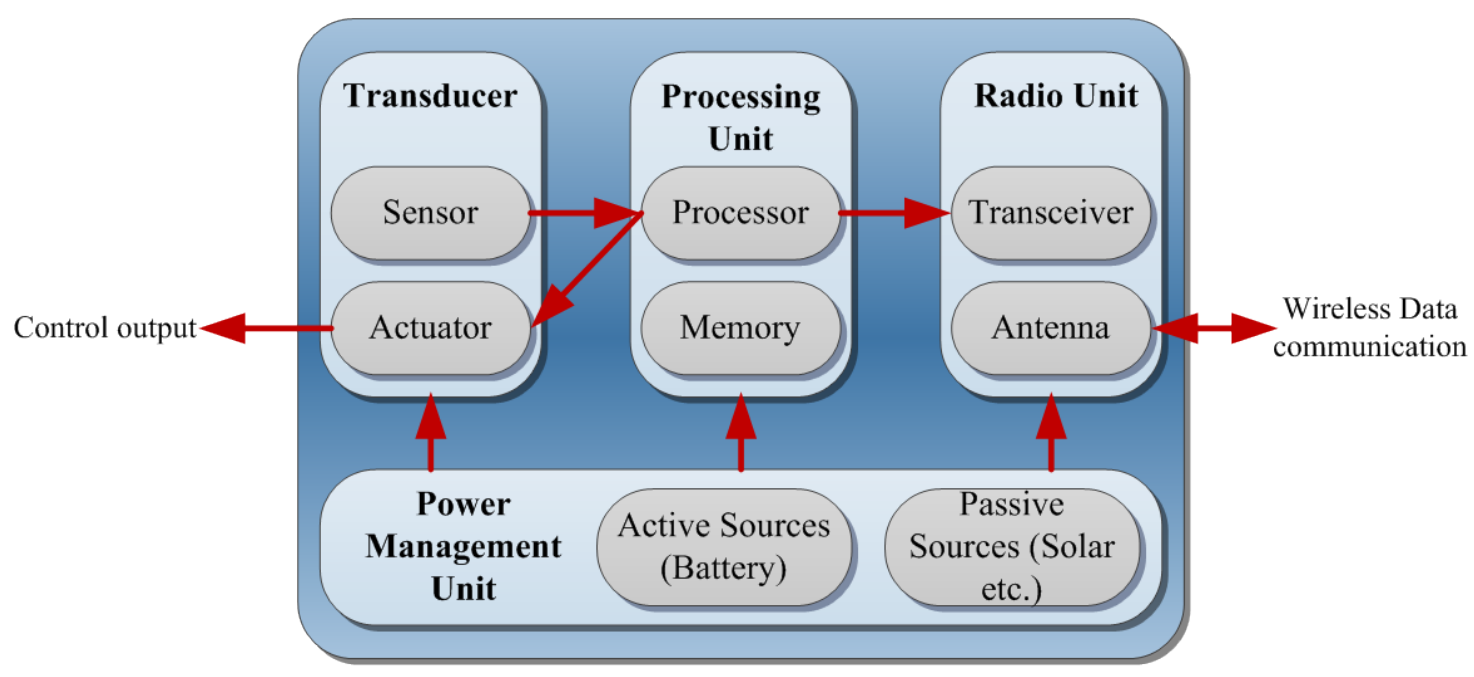

Figure 2: Sensor Node Architecture

It is reasoned that sudden fluctuations in water quality and quantity can be monitored using high frequency continuous measurements, and considerable differences in measurements are observed in daily/hourly readings in comparison to sparse readings (O'Flynn et al., 2010, Kirchner et al., 2004). Advancements in micro-electromechanical systems (MEMS), low-power and low-cost microcontrollers and radio modules enabled WSNs for environmental monitoring (Estrin et al., 2001), which overcame the limitations of previous expensive, and bulky monitoring equipment with low spatio-temporal resolution to a certain extent. WSNs are networks of small embedded computers referred to as sensor nodes or 'motes', spatially distributed to cooperatively monitor environment and transmit data wirelessly. The relatively low cost of a WSN allows in principle, the deployment of a dense population of nodes that can adequately represent the variability present in the environment. WSNs have been used for monitoring and managing farming activities (Wang et al., 2006, Ruiz-Garcia et al., 2009) and eco-hydrologic processes (Regan et al., 2009, Rundel et al., 2009). Water quality parameters such as pH, dissolved oxygen (DO), turbidity, salinity and nitrates have been measured in the reviewed applications using WSNs.

A basic sensor node (Figure 2) contains units for sensing and actuating, data processing, RF communications and power supply management (Jafer et al., 2010). A node can have many different types of sensors, for example measuring humidity, temperature, turbidity and nitrate but it should be noted that the quality of the data is dependent on the quality of the sensor. The acquired analogue samples are converted into digital signals using an on-board analogue-to-digital converter. The microprocessor may collect samples over time and aggregate them before transmitting them through the local radio transceiver to another node or a data sink (also termed as a gateway). Information collected from all the nodes is aggregated at the data sink and transmitted to and analysed at an off-field control node where a decisions might be taken. This could involve sending some actuation signal back to the network, for instance turning on sprinklers to irrigate the field. Furthermore, alternative networking approaches exist where information is processed and used entirely within the network, without the need for a central control node. Figure 3 illustrates individual networks, under different stakeholders, in farms and water inlet. 

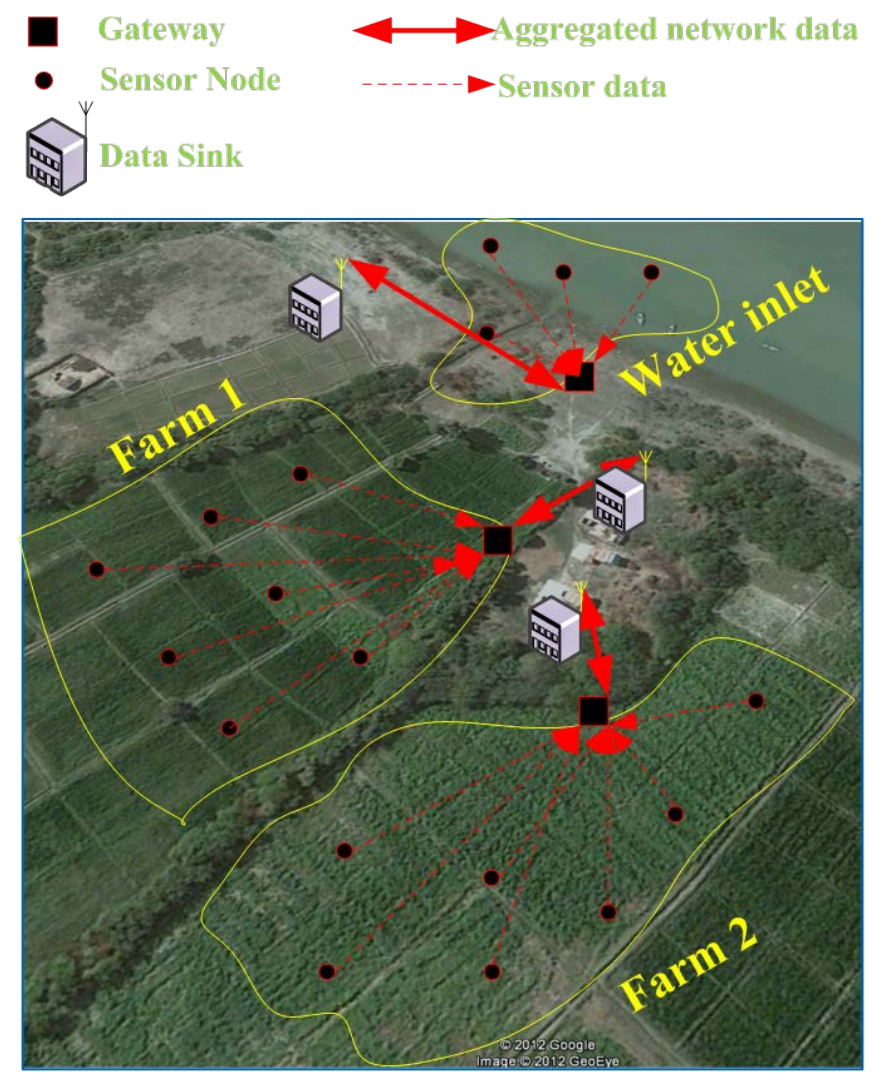

Figure 3: Data flow through WSNs deployed in a catchment

\section{WSNS FOR WATER QUALITY MONITORING AND MANAGEMENT}

WSNs have been employed for water quality monitoring of surface water (rivers, lakes, and dams), ground water, soil-water and catchments. These water bodies receive contaminants as a result of agricultural activities up in the catchment (as discussed in chapter 2). Preliminary results have been fundamental in advancing the knowledge of contaminant trends, through spatially constrained observations. Most of the applications were small scale prototype deployments and were mainly aimed at developing and testing the technology for remote, continuous and real-time data availability. These applications have yet to explore the implementation and impact of this technology for management and control decisions, in order to minimize and prevent individual stakeholder's contaminant contributions, in an autonomous and dynamic manner. When this happens, the loop would be closed and better management policies by farmers would come into place. This would require monitoring of nutrients, pathogens and chemical contributions of different farming activities responsible for water quality degradation.

WSNs have been used in agricultural activities but not specifically for WQM. For example a number of applications have been developed for precision irrigation for automatic and controlled irrigation, reducing the chances of water wastage (runoffs which are carrier of nutrients and contaminants) (McCulloch et al., 2008). However, runoff coming from elsewhere (e.g. another farm) cannot be avoided. This runoff can be carrying nutrients. In that case, current precision irrigation system can be extended to use information about runoff to modify the irrigation and fertilizer application of its field to save water and fertilizer usage. Other applications of WSNs for agriculture include pest control and animal farming. Pest control applications which are used to monitor microclimate (temperature, humidity, soil moisture) of a field to prevent conditions such as moulds etc. have been very important for viticulture (Morais et al., 2008, Beckwith et al., 2004). Furthermore, precision livestock using WSNs has been used to a) maintain animal health by monitoring environment of barns 
(Cugnasca et al., 2008, Darr and Zhao, 2008) and b) manage cow herds in a virtual moving fence to control pasture area (Butler et al., 2004, Nadimi et al., 2008).

The following sections review the applications of WSNs for WQM of different environmental compartments. Furthermore, the potential of including WSN-controlled existing agricultural activities, for integrated water quality management, is presented.

\subsection{Application of WSNs for Monitoring Water Fluxes and Quality in Different Environmental Compartments}

These projects are discussed below with respect to the area they monitor in a catchment.

\subsubsection{Groundwater Monitoring}

Groundwater contamination from human impacts is less obvious than surface water and cleaning it is more costly and technically demanding (Zektser and Lorne, 2004). Once polluted it may transport nutrients and chemicals to coastal waters (Gallagher et al., 1996, Valiela et al., 1999). WSNs have been used to measure rate, quantity and direction of water contamination flow in two different scenarios, one being to understand prevalence of arsenic in Bangladesh ground water, and the other to monitor nitrate propagation through soils and groundwater in parts of the USA. Although sensor nodes have become inexpensive, the high cost of some sensors (e.g. ammonium) is a major barrier for dense deployment of WSNs (Ramanathan et al., 2006).

In order to monitor saltwater intrusion into coastal aquifers, WSN have been deployed for monitoring water quality in a coastal area in Australia. Preliminary data showed potential for helping in decision support related to placement of extraction bores for irrigation to avoid groundwater degradation. However, it was not possible to set up a well-connected radio link in this particular humid environment (Le Dinh et al., 2007).

\subsubsection{Surface Water Monitoring}

A test deployment project, 'Lakenet', was undertaken for water quality monitoring in a eutrophic lake by University of Notre Dame (Seders et al., 2007). The sensor pod system, consisting of MICA2 and MDA300 sensor board measuring temperature, dissolved oxygen, and $\mathrm{pH}$ was deployed for a short term (10 days). The primary objective of this deployment was to test the design of both the pods and the network under field conditions and to examine its ability to collect data continuously and reliably. This project was termed successful on the basis of collected data which showed diurnal fluctuations.

To demonstrate the need for availability of high temporal rate data, as a requirement of water framework development (WFD), a WSN project (DEPLOY) was deployed at various locations on a river basin in Ireland. It achieved continuous sampling of parameters including conductivity, $\mathrm{pH}$, chlorophyll, $\mathrm{DO}$ and temperature. The system consists of the Tyndall programmable system-on-chip sensor interface and data telemetry system using IDS data pod, and an optimized RF section to provide up to $4 \mathrm{~km}$ transmission). Results showed fluctuations in measurements due to activities such as runoff, rainfall or release of water from dams in the river. This demonstrated the potential for catchment behavioural analysis using statistical processing and interpretation. However, sensor fouling and maintenance issues were raised (Regan et al., 2009, O'Flynn et al., 2010).

Similarly, another deployment involved performance evaluation of a prototype network of wireless nodes (Sunspot) on a dam in Malawi, Africa to counter severe health threats caused by degrading water quality. Water parameters such as acidity $(\mathrm{pH}), \mathrm{DO}$ and turbidity were measured by integrating a sensor board with a sensor node. These measurements were then compared with numeric standards to decide on the suitability of water for drinking (Zennaro et al., 2009).

Another application intended for WQM on dams utilizes a combination of satellite remote sensing and WSN to enable real time analysis of satellite and surface data for overall coverage and the continuous monitoring of water quality. A floating sensor platform (buoy) is developed and deployed on a dam in Cyprus which transfers water quality data via wireless network to a remote central database (Papoutsa et al., 2010).

Considerable research on developing technology to enable contaminant transport assessment and characterising urban stream quality and algal dynamics has been undertaken by CENS (Centre for Embedded Sensors), UC Los Angeles (Harmon et al., 2009, Gilbert, 2010). This started in 2007, by developing a test-bed for salinity, nitrate 
and soil moisture control in a 30acre land by using automatic irrigation control (Park and Harmon, 2007). Later progress on developing nitrate sensors for groundwater, soils and aquatic systems was made in 2009 (Ratâko et al., 2009). In 2010-2011, the project continued to focus on high resolution river observations using integrated sensing and model-driven analysis. Sensing is focused on temperature, dissolved oxygen and nitrate changes in the river (Harmon et al., 2009).

For monitoring impact of poor water quality on aquatic life, parameters such as $\mathrm{pH}$, dissolved oxygen, turbidity, salinity and electrical conductivity have been measured in various applications (He et al., 2011, Zhu et al., 2010). Real time information about these aquaculture environmental parameters can provide the means to give early warning signals. In one of the applications, based on historical data, the system was used to forecast water quality with artificial neural networks and control water quality in time to reduce the threat to fish farms. The model for forecasting dissolved oxygen half an hour ahead was validated with experimental data (Zhu et al., 2010).

\subsubsection{Soil-Water monitoring}

Monitoring drainage water of farms enables assessment of its quality. In this application (Kim et al., 2011), wireless lysimeter sensing stations were used $90 \mathrm{~cm}$ below the soil surface to monitor water flux leached below root zone under an irrigated cropping system. Continually monitored soil-water and weather data, sensed by a distributed network of sensors, was wirelessly transmitted to a base station using Bluetooth, which was connected to a web server for broadcasting the data via the internet. This provided remote online access to drainage water flux and field conditions for the whole growing season. This was targeted at measuring volume of drainage water based on irrigation frequency and rainfall events for different crops. However, this work could be easily extended to also monitor nutrient or salt parameters leached out from the soil. Another important project demonstrated the potential of WSNs for measuring soil water content, which was shown to be helpful in controlling hydrologic fluxes (Bogena et al., 2010).

\subsubsection{Catchment Monitoring}

Some work has been reported at catchment scale for water quality monitoring. Such catchments include mountains, forests, lakes, rivers, and agricultural lands. These are prototype deployments aimed at developing the technology and algorithms for large-scale remote monitoring and data processing for large volumes of heterogonous data for water quality. These are fundamental research efforts in this domain but improvements can be made.

To find causes and interactions of physical/chemical variability on rivers and estuaries, work was started by US Geological Survey on creating a wireless catchment in Santa Margarita Ecological Reserve in Southern California. It was intended for high density monitoring of the catchment encompassing mountains, canyons and river channels. The system was primarily focused on developing and testing a network of radios and routers for wireless data transmission and its availability on the internet. Various issues were faced due to rugged topography and the difficulty of obtaining line-of sight communication. Despite these challenges, this provided an effective way of remote monitoring and was used further for monitoring meteorological properties related to pollutant loadings (Cayan et al., 2003).

Similarly, for evaluating variation of regional weather, at mountain-to-sea scale, on water quality/quantity, and flooding in a catchment in Hawaii, a prototype system to provide 3D geospatial data visualization utilizing WSN was proposed. The system consisted of an array of nodes consisting of water quality sensors (temperature, $\mathrm{pH}$, conductivity, dissolved oxygen, and turbidity), weather stations, sensor data loggers (InteleCell), and video monitors. Preliminary results showed improvement over traditional sampling methods (Kido et al., 2008).

The 'SoilWeather' network was used in Finland for providing high temporal resolution on weather conditions, soil moisture and water quality (Kotamäki et al., 2009). The work was reported to have been used in developing a leaching model at sub catchment scale, including an improved hydrological model of the river, for monitoring water quality and nutrient retention in rivers and wetland. The network was deployed on a catchment covered by forests, river, lakes, and agricultural lands owned by private owners, who were the main users of the data. This is an important work highlighting data quality and processing issues with high volumes of heterogeneous data, 
received from catchment-scale observation using a single network, varying in content, accuracy, and spatialtemporal resolution. Additionally, maintenance of sensors due to such issues as bio-fouling, freezing, and rain gauge problems, which resulted in erroneous and missing data were viewed as major challenges in obtaining high data quality.

\subsection{Leveraging Current Agricultural Processes for Water Quality Monitoring and Management}

Some of the key research areas in precision agriculture which have received considerable attention include precision irrigation, pest control, viticulture and animal health monitoring (Wang et al., 2006, Ruiz-Garcia et al., 2009). Instead of taking decisions based on hypothetical average conditions, the real time information from these systems provides a solid basis for farmers to adjust strategies at any time (Ruiz-Garcia et al., 2009). There is a potential of leveraging existing networked agricultural activities for their extension into an integrated water quality management mechanism. In this regard, current agricultural processes such as pest control, precision irrigation and animal farming which are monitored and controlled using WSN are discussed below.

\subsubsection{Pest Control:}

To determine and prevent the onset of a fungal disease, phytophtora, in a potato field, a network of sensor nodes was deployed to sense humidity and temperature. Sensed data was sent periodically to a gateway at the edge of the field from where it was forwarded to a server using Wi-Fi. The accumulated field data for a day was then fed into a decision support system server where it was combined with weather forecast to determine the treatment policy each morning, rather than spraying pesticides based on hypothetical assumptions. This experiment, though based on specialized hardware, still presented many challenges for radio coverage owing to crop canopy effect, routing protocol, software bugs and in-field deployment (Langendoen et al., 2006). It has had tremendous impact on improving deployment and practicality issues in WSN applications (Le Dinh et al., 2007, Liang and Terzis, 2008). Furthermore, to prevent frost, pest and mould damage in vineyards, which are prone to quick damage if overstressed, WSNs have been used to monitor ambient temperature, soil moisture and soil temperature (Morais et al., 2008, Beckwith et al., 2004). This information enables vineyard owners to monitor the plants remotely and manage priorities accordingly (Burrell et al., 2004).

These pest control applications could be extended, to include chemical sensing, in order to assess chemical levels in the crops and soil after pesticides and herbicides applications. Information obtained through such a mechanism could then be used to inform on and thus potentially control chemical fluxes into water bodies.

\subsubsection{Animal Farming:}

In order to maintain and improve animal health within animal feeding operations (AFO) and to prevent its negative impact on the ecosystem, information related to the local environment is very important. Moreover, by having a mechanism to monitor and control animal herds in pasture lands, pathogen and organic additions to the environment may be controlled and assessed. The deployment of WSNs in many AFOs has enabled monitoring of parameters such as temperature, humidity, noise and ammonia content in the air which has allowed the management and maintenance of healthy environments in these facilities (Cugnasca et al., 2008, Darr and Zhao, 2008).

For managing cattle herds in pasture land, an algorithm called 'moving virtual fence' was developed. Each animal in the herd was given a smart collar consisting of a GPS (for determining animal's location), a PDA, a WLAN card and a sound amplifier. As the animal approached a perimeter, it is presented with an acoustic stimulus to drive it away from crossing over a designated virtual boundary. By dynamically shifting fence lines, the usage of feedlots is improved. In addition, it reduced the overhead of installing and moving physical fences (Butler et al., 2004). Other work has investigated online monitoring of cattle presence and pasture time using WSNs to register the time animals spend in specific areas of the field (Nadimi et al., 2008). This information can be used to indicate grass quality and quantity and can also determine the right time to provide access to a new grass strip. 
These applications can be clearly extended to monitor pathogen levels animal waste in a barn and their fluxes to water bodies and therefore manage it by raising alerts. Also, by managing animal herds with a virtual fence, the possible situation of them contaminating water bodies or others fields can be avoided or reduced.

\subsubsection{Precision Irrigation}

As established in the introduction, potable water resources are under pressure. Therefore an efficient way of utilizing water resources by people in general and agriculture sector in particular is crucial to avoiding a global water crisis (Chartres and Varma, 2011).

By monitoring soil and environmental parameters (like soil moisture, soil temperature, ambient temperature and humidity), an informed decision can be made by farmers to control the timing and quantity of irrigation. Unlike expensive, sophisticated, high maintenance and high energy sensor-based technologies like Adcon Telemetry and Automata, and labour intensive data collection from logging stations, WSNs provide real-time and less expensive sensing mechanisms for improving irrigation automation (Vellidis et al., 2008).

It is estimated that $70 \%$ of the annual water usage of the agricultural industry, in the Australian state of Tasmania, is used to irrigate dairy pastures. In order to improve water use efficiency for pasture production, data is collected using 70 sensor pods which were developed using off-the-shelf components for this experiment. Accurate irrigation at targeted dry areas can be provided by studying soil dynamics, using soil and environmental parameters collected from the pasture field. Received data showed variation in soil moisture levels with events such as rains etc. (McCulloch et al., 2008).

Another example made a comparison between traditional and sensor scheduling systems in a cotton field (2.3 ha) for the whole growing season (Vellidis et al., 2008). The East of the field, divided into four different irrigation zones based on soil type and historic yield map, was equipped with 9 sensor nodes and centre pivot variable rate irrigation (VRI) system. On the western side, 3 sensor nodes were deployed to monitor soil tension, and here irrigation was triggered based on traditional assessment of crops. Each sensor node was equipped with three moisture and temperature sensors buried at 0.2, 0.4 and $0.6 \mathrm{~m}$ depth under the soil. Results showed water tension at more than double the trigger points at 0.4 and $0.6 \mathrm{~m}$ depth in western zone despite irrigation, whereas the eastern side never surpassed the trigger points. However, it is stated that further work needs to be done on the VRI controller for varying quantity of irrigation relative to the needs of individual areas, or for different crops in a single field.

To address such a need, site specific VRI was employed in a 3.6 ha plot by using six in-field sensor stations. These stations were based on off-the-shelf components, with a plug-and-play Bluetooth radio module, and would periodically sample data and transmit back to the base station. Each sensing station was equipped with water content reflectometers, a soil temperature probe, and a humidity probe. The irrigation machine was controlled by a programmable logic controller that would update the geo-referenced location of sprinklers from a differential GPS, and wirelessly communicate with a computer at the base station. This enabled variable rate irrigation according to the needs of individual crops in a large field. (Kim et al., 2008).

As discussed above, a significant amount of successful work has been published using automatic and variable rate irrigation with some limitations regarding reliability. However, what is lacking is the inclusion of real time information about events elsewhere in the farm to alter irrigation decisions. For example, information about possible weather changes, like rain, from other networks in a catchment could be used to change time and quantity of irrigation by allowing forward planning and prediction. Also, information regarding irrigation in one farm can be used elsewhere in the catchment to prohibit entry of nutrient flux from that runoff.

\section{RESEARCH GAP IN WATER QUALITY MONITORING AND MANAGEMENT USING WSNs}

The literature review for the application of WSN for water quality monitoring and agricultural activities presents many possibilities and potential, yet identifies numerous limitations. Following are the major limitations commonly observed in the reviewed literature. 


\subsection{Absence of catchment scale integrated monitoring and management}

As identified in chapter 2, a number of catchment-scale activities are responsible for water quality degradation. Therefore, to identify the individual and major impacts of the diffused pollutant sources, it is vital to base the monitoring system on the entire catchment. It has been acknowledged in the literature that the varied monitoring needs for individual areas of a catchment could be combined to allow an understanding of contaminant flow trends and quantification of the contributing factors. WSNs have been successful in understanding the trends of nutrients and contaminants fluxes owing to non-point source activities in a catchment. However, this understanding is limited as it can currently only use small-scale, localized and specific measurements at rivers, lakes, dams and groundwater reservoirs (Ramanathan et al., 2006, Le Dinh et al., 2007, Zennaro et al., 2009, Papoutsa et al., 2010, Seders et al., 2007, Harmon et al., 2007, O'Flynn et al., 2010, Regan et al., 2009). These water resources receive contaminants as a result of activities up in the catchment, thus providing insufficient information for quantifying explicit responsible activities. Fewer applications are intended for large-scale observations (Kido et al., 2008, Kotamäki et al., 2009, Cayan et al., 2003), but these are prototype deployments based on limited monitoring points across the catchment. A major step in this direction is the new network of terrestrial environmental observatories in Germany that provides real-time access to instruments in a multi-scale and multi-temporal mode for the monitoring of relevant fluxes of trace-gases, water and matter in all important environmental compartments at the catchment-scale, e.g. hydrological sensor networks, micrometeorological flux stations and clusters of lysimeters (Zacharias et al., 2011).

Existing work does not implement multi-scale monitoring mechanisms that include all stakeholders in a catchment, to assess their individual contributions, which is fundamental for the understanding of cumulative impacts on water quality degradation. Current projects are focused on the development and deployment of the required infrastructure for enabling high-temporal, real-time water-quality observations to be made available through GSM or internet on a central data repository (Kotamäki et al., 2009, Kido et al., 2008). These do not include addressing management and control decisions, to minimize and prevent individual stakeholder's nutrient/contaminant contributions, in an autonomous and dynamic manner. Thus a need can be identified for an autonomous and integrated catchment-scale monitoring mechanism, based on targeted wireless sensor technologies.

\subsection{Absence of suitable sensors}

Water quality analysis requires monitoring of various parameters as represented in the tabulated contaminant constituents (Table 1). It is apparent that the advances in sensor development have not kept pace with the advances in potential sensor materials (Zhuiykov, 2012). The development of sensors from new materials to enable solid-state and film-based sensors requires significant development effort before they can be used in real applications, although they do offer significant potential. An example of an improved sensor is the development of a solid-state water quality sensor with metal oxide sensing electrodes under research efforts by Commonwealth Scientific Industrial Research Organisation (CSIRO). This has provided the capability to measure pH, DO and dissolved metal ions in a way more appropriate for WSN applications (Zhuiykov, 2007, Zhuiykov, 2012). It is evident through the surveyed literature that existing work does not include all of the contaminants and parameters required for water quality monitoring, for example phosphorous, nitrates, and ammonia. This is because suitable in-situ phosphate and nitrate sensors for terrestrial deployment are not available. The available sensors for nitrate monitoring are based on ultraviolet absorption and flow cell analysers which are very expensive for dense deployment (Robertson et al., 2009). Both electromechanical (Bobacka et al., 2008) and optical sensing modes (McDonagh et al., 2008) relevant to nitrogen and phosphorous species are still an active research area (Rundel et al., 2009). Furthermore, research on the development of miniature, reliable and inexpensive water quality solid-state sensors using metal oxide sensing electrodes is underway by CSIRO, CMSE and SSN TCP laboratories (Zhuiykov, 2012).

In the absence of affordable and reliable in-situ sensors for all of the necessary water quality parameters, estimation of constituent fluxes in streams and rivers relies on surrogate sensors which give proxy measurements. Examples include use of turbidity (clarity of water) and fluorescence intensities as a surrogate for suspended sediments and biochemical oxygen demand (Minella et al., 2008, Hudson et al., 2008). Another study 
demonstrated successful surrogate relationship, for road and roof surfaces, of dissolved total nitrates and total phosphates with total dissolved solids (TDS). For measuring TDS, electrical conductivity was used as a surrogate (Miguntanna, 2009) . These surrogates have been fundamental in advancing our knowledge about the trends in the actual parameters. However it is also noted that measurement error and uncertainty in the derived surrogate relationships can have a substantial effect on the uncertainty of flux estimates made using surrogates (Horsburgh et al., 2010) and require significant calibration of the environments in which they are deployed. Although sensor development is on-going (Zhuiykov, 2012), there are still few useable sensors for many of the parameters, thus it can be concluded that there is a requirement for accurate, inexpensive, low-power, long-lived, robust and miniature sensors for effective water quality analysis.

\subsection{Issues related to the use of off-the-shelf components}

Current applications of WSNs for WQM are based on the use of off-the-shelf components which often fail to address the diverse range of environmental and degradation problems that can coalesce at catchment scales. Existing devices are not made to address the specific requirements of a particular application. Various limitations, as discussed above, have been faced in the existing literature by the use of off the shelf components (Le Dinh et al., 2007) such as the coverage problem (Regan et al., 2009), signal attenuation (Vellidis et al., 2008), configuration and operational difficulties (Trubilowicz et al., 2009), and absence of a network model for catchment areas with hilly terrains which has the potential to affect the radio links.

Standards for WSNs were developed primarily for urban monitoring situations such as buildings and industries. However, they are less suited to remote and large scale applications such as agriculture with coverage and crop canopy problems due to the propagation environment and typical range requirements. For example, high frequency systems (typically 2.4GHz) commonly rely on line-of-sight systems and physical obstructions such as plants, or conditions such as rain, can significantly reduce the communication range to as little as a few meters. Furthermore, these frequencies are unsuitable for underground WSNs, which are ideal for non-invasive soil monitoring, as they suffer data losses due to soil water content (Akyildiz and Stuntebeck, 2006, Li et al., 2007). In an experiment, sensor and link failures were handled by 1) identifying patterns in data to indicate sensor failure and 2) using decision trees based on data flow models to identify link failure (Ramanathan et al., 2006).

Top level concepts and protocols are applicable without any changes but care is needed for practical deployment and it may be that certain applications require a significant rethink of the communication requirements, which may not be addressed by current off-the-shelf solutions. This is an on-going research for the application of underground wireless sensor networks. (Bogena et al., 2009) evaluated signal attenuation by factors like soil depth, soil water content and soil electrical conductivity. They concluded that in a hybrid underground approach, which combines below ground and above ground data transmission, sufficient power will remain to ensure long distant data communication.

As long term and spatiotemporal monitoring is required for effective analysis of water degradation trends in a catchment, a low cost, low power and reliable system is required. Existing literature has shown that many nodes lasted from only a few days to months, therefore effective design changes like wake up and power control need to be considered to prolong their lifetime to years.

Furthermore, although separate sensor boards (Zennaro et al., 2009, O'Flynn et al., 2007) can be integrated with nodes to enable a multi sensing system with various sensor types, improvements can be made to take this further. The plug and play system constrains sensors to be compatible with that system, whereas a more reconfigurable interface may well extend the choice of sensors at the expense of some complexity in specifying to the host node what the sensor requires in terms of resources. Therefore, there is a requirement for a reconfigurable sensor interface for a sensor node, e.g. SDI-12, as this would allow a more rapid deployment for a specific application and thereby reducing the costs of the WSNs. In addition, various deployment and maintenance issues were faced due to the placement of sensors in soil and water. Bio-fouling of sensors deployed in water required regular cleaning and maintenance (Regan et al., 2009). 


\section{A CASE FOR COLLABORATIVE WSNS FOR INTEGRATED CATCHMENT-SCALE WATER QUALITY MANAGEMENT}

Through the review of related work and its limitations, it is established that for effective water quality management at a catchment scale, a system of individually networked activities needs to be included into an integrated monitoring system. Information sharing of critical parameters between networked environmental compartments and WSN-controlled agricultural activities can enable identification and quantification of the contributing factors in water degradation. This would further address management and control decisions, to minimize and prevent individual stakeholder's nutrient/contaminant contributions, on waterways as well as on other stakeholders, in an autonomous and dynamic manner (Zia et al., 2013). Figure 4 illustrates information sharing among individual networks in a catchment.

It is proposed that monitoring should be based on three levels covering the micro-to macro- scales. Micro-scale monitoring is aimed at improved understanding of small scale processes such as leaching of nutrients in soil and groundwater and retention of fertilizers by soil. Then a medium scale monitoring which is focused on assessing agricultural practices such as improved irrigation strategies, and use of alternative fertilizers or reduced application rates while maintaining same crop yields. Finally, macro-scale monitoring considers catchment level, sub-catchment level and regional land use assessments.

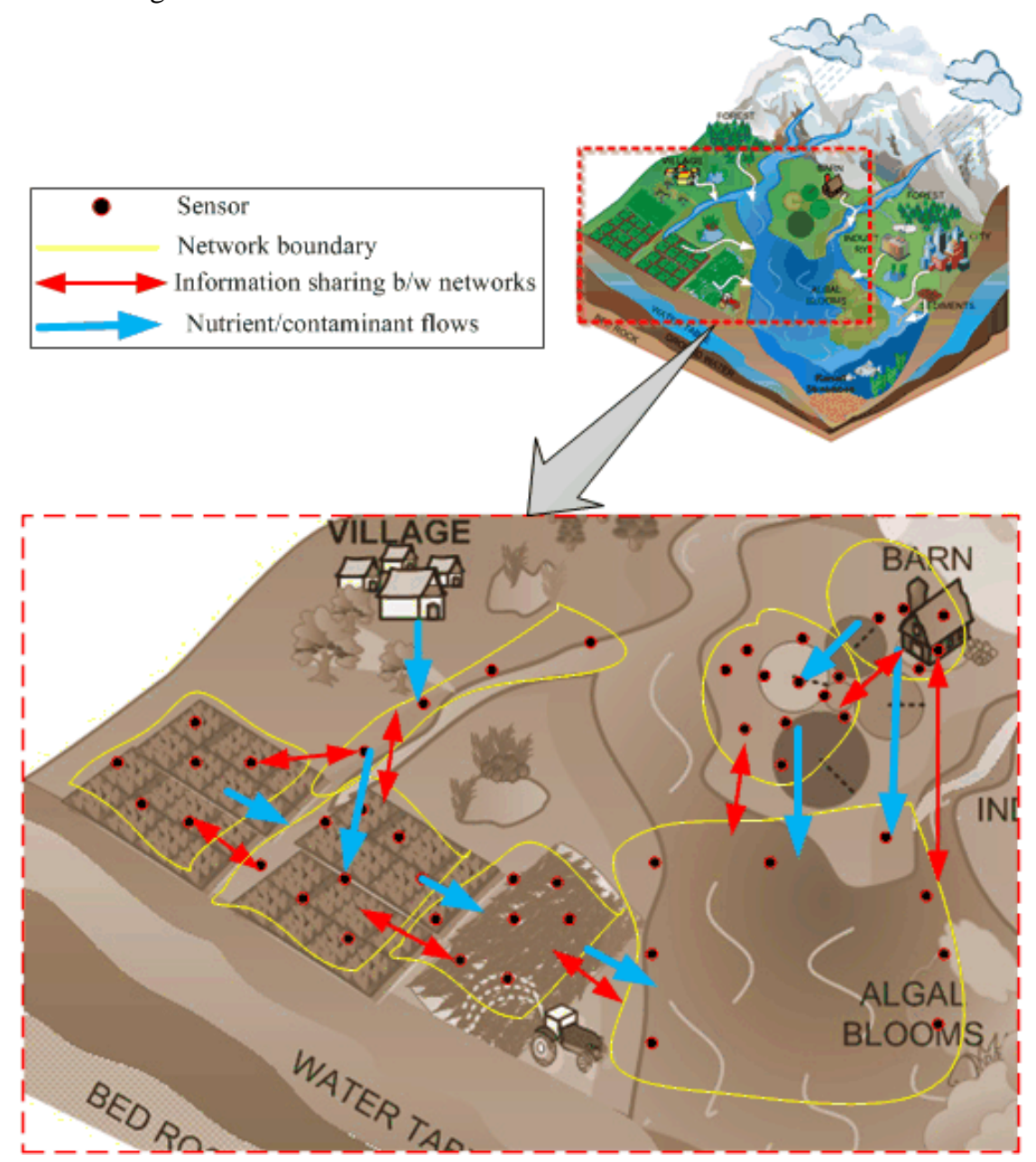

Figure 4: Collaborative Catchment-Scale Management using Integrated WSNs

Monitoring environmental compartments continuously and spatially can identify specific local sources for nutrient/contaminant fluxes (e.g. a barn or a farm). If this information is fed back to the identified stakeholder in real time, there is the potential to control or minimise the fluxes emanating from the location. If there are other networks monitoring nutrient/contaminant levels and fluxes near the source location, then the information 
provided by these networks can be correlated with data from the original monitoring point. If it correlates well then this has identified a route from the source to the appropriate nearby network as well as characterising that route in terms of quantity and time constant, thus allowing a model of cause and effect to be built up for the locality. Based on this information, the responsible stakeholder can then assess its adopted practices and alter strategies to reduce its contribution to water quality degradation.

A collaborative control and management strategy requires that individually targeted monitoring units or local networks, representing different stakeholders in a catchment e.g. a farm, should be able to share information with each other about runoffs, contaminants or nutrient fluxes. These events may be intense but are short-lived and so information sharing becomes important as they may be very fast compared with the usual sampling rate, and so may normally be missed. Allowing event information to be transmitted across multiple networks as they are detected will allow prediction of when the repercussions of that event might be seen downstream, allowing other stakeholder networks in the vicinity to adjust their monitoring strategy to improve the value of information e.g. by increasing their sample rate to catch transient events. This would than support the development of advanced models that are able to simulate catchment processes in a more detailed way. Implementing such a mechanism allows every stakeholder the option to contribute and use any data flowing through the catchment from other networks.

\section{CONCLUSION}

This paper has reviewed the potential impact of agricultural activities on water quality degradation in a catchment. It has proposed that the varied monitoring needs for individual areas of a catchment could be combined to allow an understanding of contaminant flow trends, their quantification and management of the contributing factors. This identifies a need for an autonomous and collaborative mechanism, based on targeted wireless sensor technologies. Furthermore, it is concluded that for effective and integrated water quality monitoring and management at a catchment scale, a system of individually networked activities is needed. This is likely to take the form of a combination of networks that have been installed for local monitoring purposes (e.g. at farm scale, primarily to provide local information for that farm), and some specific networks aimed at filling in information gaps in the catchment. This system of networks should be able to share information about critical parameters for events, such as rain, or floods, that could trigger consequences, such as contaminants runoff and so requires a higher level application to make use of this information, and also requires the individual networks to be aware that similar networks nearby are capable of passing information to them. This will inevitably lead to some form of standardisation of communication protocol and data representation between enabled environmental networks.

Applications of WSNs for water quality monitoring and management for a catchment hold huge potential. However, certain limitations have been identified in this review such as small scale, single application deployments, limitations of off-the-shelf components, the lack of suitable sensors and the cost of deployment and data collection. Furthermore, it is determined that important application specific requirements are not well catered for by using off-the-shelf components such as variable sampling rates, well-defined and flexible sensor interfaces, lifetime, ease of deployment and configuration for hydrologists, and a network model for the broader environment.

Hence, it is emphasized that although there is continual and improving design of sensor nodes for individual applications there is still a requirement for more flexibility in node design with a view to allowing networks to successfully interact with each other. In the absence of affordable and reliable in-situ sensors for WQM, measurements rely on surrogate sensors which give proxy measurements. Therefore, it is concluded that there is still a need for accurate, inexpensive and miniature sensors with a long field life for WQM.

Nevertheless, developments on all these areas are on-going, and as such deficiencies are addressed, the ability to monitor at catchment scales will improve. We argue that by implementing a collaborative mechanism that allows every stakeholder the option to contribute and use any data flowing through the networks, the overall value of that information will be increased. 


\section{REFERENCES}

AKYILDIZ, I. F. \& STUNTEBECK, E. P. 2006. Wireless underground sensor networks: Research challenges. Ad Hoc Networks, 4, 669-686.

BASHA, E. \& RUS, D. Design of early warning flood detection systems for developing countries. Information and Communication Technologies and Development, 2007., 2007. IEEE, 1-10.

BECKWITH, R., TEIBEL, D. \& BOWEN, P. Report from the field: results from an agricultural wireless sensor network. IEEE Local Computer Networks, 2004, 2004. IEEE, 471-478.

BELLWOOD, D., HUGHES, T., FOLKE, C. \& NYSTRÖM, M. 2004. Confronting the coral reef crisis. Nature, 429, 827-833.

BLANCO, G., LEMUS, J. A. \& GRANDE, J. 2009. Microbial pollution in wildlife: Linking agricultural manuring and bacterial antibiotic resistance in red-billed choughs. Environmental research, 109, 405-412.

BOBACKA, J., IVASKA, A. \& LEWENSTAM, A. 2008. Potentiometric ion sensors. ChemInform, 39.

BOGENA, H., HERBST, M., HUISMAN, J., ROSENBAUM, U., WEUTHEN, A. \& VEREECKEN, H. 2010. Potential of wireless sensor networks for measuring soil water content variability. Vadose Zone Journal, 9, 10021013.

BOGENA, H., HUISMAN, J., MEIER, H., ROSENBAUM, U. \& WEUTHEN, A. 2009. Hybrid wireless underground sensor networks: Quantification of signal attenuation in soil. Vadose Zone Journal, 8, 755-761.

BOLSTAD, P. V. \& SWANK, W. T. 1997. CUMULATIVE IMPACTS OF LANDUSE ON WATER QUALITY IN A SOUTHERN APPALACHIAN WATERSHED1. JAWRA Journal of the American Water Resources Association, 33, 519-533.

BORJA, A., FRANCO, J., VALENCIA, V., BALD, J., MUXIKA, I., JESÚS BELZUNCE, M. \& SOLAUN, O. 2004. Implementation of the European water framework directive from the Basque country (northern Spain): a methodological approach. Marine pollution bulletin, 48, 209-218.

BURRELL, J., BROOKE, T. \& BECKWITH, R. 2004. Vineyard computing: Sensor networks in agricultural production. Pervasive Computing, IEEE, 3, 38-45.

BUTLER, Z., CORKE, P., PETERSON, R. \& RUS, D. "Virtual fences for controlling cows". Robotics and Automation, 2004. , 2004. IEEE, 4429-4436 Vol. 5.

CARPENTER, S. R., CARACO, N. F., CORRELL, D. L., HOWARTH, R. W., SHARPLEY, A. N. \& SMITH, V. H. 1998. Nonpoint pollution of surface waters with phosphorus and nitrogen. Ecological applications, 8, 559568.

CAYAN, D., VANSCOY, M., DETTINGER, M. \& HELLY, J. 2003. The Wireless Watershed at the Santa Margarita Ecological Reserve. Southwest Hydrology, 2, 18-19.

CEREJEIRA, M., VIANA, P., BATISTA, S., PEREIRA, T., SilVA, E., VALÉRIO, M., SILVA, A., FERREIRA, M. \& SILVA-FERNANDES, A. 2003. Pesticides in Portuguese surface and ground waters. Water Research, 37, 1055-1063.

CHARTRES, C. J. \& VARMA, S. 2011. Out of water: from abundance to scarcity and how to solve the world's water problems, Ft Pr.

COLES, N., CALLOW, N., COHEN, B. \& POPE, T. 2009. Using engineering concepts to manage ecohydrologic processes driving biodiversity decline due to increased surface runoff in low-gradient dryland catchments. 2nd International Multidisciplinary Conference on Hydrology and Ecology 2009 Ecosystems interfacing with Groundwater and Surface Water. Vienna, Austria.

CUGNASCA, C., SARAIVA, A., NÄÄS, I., DE MOURA, D. \& CESCHINI, G. Ad Hoc Wireless Sensor Networks applied to animal welfare research. Livestock Environment VIII, American Society of Agricultural and Biological Engineers (ASABE), 2008.

DARR, M. \& ZHAO, L. A wireless data acquisition system for monitoring temperature variations in swine barns. 2008. International Commission of Agricultural Engineering (CIGR), Institut fur Landtechnik.

DAUGHTON, C. G. 2004. Non-regulated water contaminants: emerging research. Environmental Impact Assessment Review, 24, 711-732.

EPA 2009. National Water Quality Inventory: Report to Congress ; 2004 Reporting Cycle. Washington, DC: United States Environmental Protection Agency. 
EPA, U. E. P. A. 2012. Basic Information about Pathogens and Indicators in Drinking Water [Online]. Available: http://water.epa.gov/drink/contaminants/basicinformation/pathogens.cfm.

EPA, U. S. E. P. A. Collecting Water-Quality Samples For Dissolved Metals-In-Water; Compiled by Forrest B. John [Online].

Available:

http://www.epa.gov/region6/qa/qadevtools/mod5_sops/surface_water_sampling/low_level_metals/r6wtr-

sampling-metals.pdf.

ESTRIN, D., GIROD, L., POTTIE, G. \& SRIVASTAVA, M. Instrumenting the world with wireless sensor networks. Acoustics, Speech, and Signal Processing (ICASSP '01). , 2001. IEEE, 2033-2036

FAO 1996. Control of water pollution from agriculture, Natural Resources Management and Environment Department.

FERGUSON, C., HUSMAN, A. M. D. R., ALtAVILlA, N., DEERE, D. \& ASHBOLT, N. 2003. Fate and Transport of Surface Water Pathogens in Watersheds. Critical Reviews in Environmental Science and Technology, 33, 299-361.

GAllagher, D. L., DIETRICH, A. M., REAY, W. G., HAYES, M. C. \& SIMMONS JR, G. M. 1996. Ground water discharge of agricultural pesticides and nutrients to estuarine surface water. Ground Water Monitoring \& Remediation, 16, 118-129.

GILBERT, R. M. 2010. A multi-method approach for the characterization of urban stream quality and algal dynamics. UNIVERSITY OF CALIFORNIA, LOS ANGELES, ISBN 1243747714.

GLASGOW, H. B., BURKHOLDER, J. A. M., REED, R. E., LEWITUS, A. J. \& KLEINMAN, J. E. 2004. Real-time remote monitoring of water quality: a review of current applications, and advancements in sensor, telemetry, and computing technologies. Journal of Experimental Marine Biology and Ecology, 300, 409-448.

GUZZELLA, L., POZZONI, F. \& GIULIANO, G. 2006. Herbicide contamination of surficial groundwater in Northern Italy. Environmental Pollution, 142, 344-353.

HARMON, T., JAY, J., SAEZ, J., KAISER, W., MARGULIS, S., RAT'KO, A., LIN, C.-C., FISHER, J., WU, C.-C., BUTLER, C., BUCHANAN, D., BYRN, G., PAI, H., HAVENS, K., HERMOSILLO, M., RANANATHAN, N., BARNES, P., VILLAMIZAR AMAYA, S., STATHOPOULOS, T., LIN, T. \& PARK, Y. 2009. An Overview of CENS Contaminant Transport Observation and Management Research, UC Los Angeles: Center for Embedded Network Sensing, http://www.escholarship.org/uc/item/9mj6b80x.

HARMON, T. C., AMBROSE, R. F., GILBERT, R. M., FISHER, J. C., STEALEY, M. \& KAISER, W. J. 2007. High-resolution river hydraulic and water quality characterization using rapidly deployable networked infomechanical systems (nims rd). Environmental Engineering Science, 24, 151-159.

HE, D., LI, D., BAO, J., JUANXIU, H. \& LU, S. 2011. A Water-Quality Dynamic Monitoring System Based on Web-Server-Embedded Technology for Aquaculture. Computer and Computing Technologies in Agriculture IV, 725-731.

HEIMLICH, R. 2003. Agricultural Resources and Environmental Indicators, 2003. Agriculture Handbook. USDA, Economic Research Service.

HORSBURGH, J. S., SPACKMAN JONES, A., STEVENS, D. K., TARBOTON, D. G. \& MESNER, N. O. 2010. A sensor network for high frequency estimation of water quality constituent fluxes using surrogates. Environmental Modelling \&amp; Software, 25, 1031-1044.

HUDSON, N., BAKER, A., WARD, D., REYNOLDS, D. M., BRUNSDON, C., CARLIELL-MARQUET, C. \& BROWNING, S. 2008. Can fluorescence spectrometry be used as a surrogate for the Biochemical Oxygen Demand (BOD) test in water quality assessment? An example from South West England. Science of The Total Environment, 391, 149-158.

HUNTER, H. M. \& WALTON, R. S. 2008. Land-use effects on fluxes of suspended sediment, nitrogen and phosphorus from a river catchment of the Great Barrier Reef, Australia. Journal of Hydrology, 356, 131-146.

JAFER, E., O'FLYNN, B., O'MATHUNA, C. \& WANG, W. Design of miniaturized wireless sensor mote and actuator for building monitoring and control. 2010. IEEE, 887-892.

KIDO, M. H., MUNDT, C. W., MONTGOMERY, K. N., ASQUITH, A., GOODALE, D. W. \& KANESHIRO, K. Y. 2008. Integration of Wireless Sensor Networks into Cyberinfrastructure for Monitoring Hawaiian "Mountain-to-Sea” Environments. Environmental Management, 42, 658-666.

KIM, Y., EVANS, R. G. \& IVERSEN, W. M. 2008. Remote sensing and control of an irrigation system using a distributed wireless sensor network. Instrumentation and Measurement, IEEE Transactions on, 57, 1379-1387. 
KIM, Y., JABRO, J. D. \& EVANS, R. G. 2011. Wireless lysimeters for real-time online soil water monitoring. Irrigation Science, 29, 423-430.

KIRCHNER, J. W., FENG, X., NEAL, C. \& ROBSON, A. J. 2004. The fine structure of water-quality dynamics: the (high-frequency) wave of the future. Hydrological Processes, 18, 1353-1359.

KOTAMÄKI, N., THESSLER, S., KOSKIAHO, J., HANNUKKALA, A. O., HUITU, H., HUTTULA, T., HAVENTO, J. \& JÄRVENPÄÄ, M. 2009. Wireless in-situ sensor network for agriculture and water monitoring on a river basin scale in Southern Finland: Evaluation from a data user's perspective. Sensors, 9, 2862-2883.

KRCHNAK, K., MARKHAM, V. D., THORNE, N. \& COPPOCK, J. 2002. Human population and freshwater resources: US cases and international perspectives, Yale University.

LANGENDOEN, K., BAGGIO, A. \& VISSER, O. Murphy loves potatoes: Experiences from a pilot sensor network deployment in precision agriculture. 2006. IEEE, 8 pp.

LE DINH, T., HU, W., SIKKA, P., CORKE, P., OVERS, L. \& BROSNAN, S. Design and deployment of a remote robust sensor network: Experiences from an outdoor water quality monitoring network. 2007. IEEE, 799806.

LEMOS, S. G., NOGUEIRA, A. R. A., TORRE-NETO, A., PARRA, A. \& ALONSO, J. 2007. Soil calcium and $\mathrm{pH}$ monitoring sensor system. Journal of agricultural and food chemistry, 55, 4658-4663.

LI, L., VURAN, M. C. \& AKYILDIZ, I. F. 2007. Characteristics of underground channel for wireless underground sensor networks. Proc. Med-Hoc-Net'07.

LIANG, C. J. M. \& TERZIS, A. Koala: Ultra-low power data retrieval in wireless sensor networks. 2008. IEEE Computer Society, 421-432.

LIPP, E. K., FARRAH, S. A. \& ROSE, J. B. 2001. Assessment and impact of microbial fecal pollution and human enteric pathogens in a coastal community. Marine pollution bulletin, 42, 286-293.

MATTHEWS, M. W., BERNARD, S. \& WINTER, K. 2010. Remote sensing of cyanobacteria-dominant algal blooms and water quality parameters in Zeekoevlei, a small hypertrophic lake, using MERIS. Remote Sensing of Environment, 114, 2070-2087.

MCCUllOCH, J., MCCARTHY, P., GURU, S. M., PENG, W., HUGO, D. \& TERHORST, A. Wireless sensor network deployment for water use efficiency in irrigation. 3rd Workshop on Real-World Wireless Sensor Networks, REALWSN 2008, April 1, 2008 - April 1, 2008, 2008 Glasgow, United kingdom. Association for Computing Machinery, 46-50.

MCDONAGH, C., BURKE, C. S. \& MACCRAITH, B. D. 2008. Optical chemical sensors. ChemInform, 39.

MCKERGOW, L. A., WEAVER, D. M., PROSSER, I. P., GRAYSON, R. B. \& REED, A. E. G. 2003. Before and after riparian management: sediment and nutrient exports from a small agricultural catchment, Western Australia. Journal of Hydrology, 270, 253-272.

MIGUNTANNA, N. S. 2009. Determining a set of surrogate parameters to evaluate urban stormwater quality.

MIN, Q. W. \& JIAO, Y. A. N. L. 2002. Effects of Agricultural Non-point Source Pollution on Eutrophica tion of Water Body and Its Control Measure [J]. Acta Ecologica Sinica, 3.

MinellA, J. P. G., MERTEN, G. H., REICHERT, J. M. \& CLARKE, R. T. 2008. Estimating suspended sediment concentrations from turbidity measurements and the calibration problem. Hydrological Processes, 22, 1819-1830.

MORAIS, R., FERNANDES, M. A., MATOS, S. G., SERÔDIO, C., FERREIRA, P. \& REIS, M. 2008. A ZigBee multi-powered wireless acquisition device for remote sensing applications in precision viticulture. Computers and Electronics in Agriculture, 62, 94-106.

MOSS, B. 2008. Water pollution by agriculture. Philosophical Transactions of the Royal Society B: Biological Sciences, 363, 659-666.

MUELLER, D. K., HELSEL, D. R. \& KIDD, M. A. 1996. Nutrients in the nation's waters: too much of a good thing?, US Government Printing Office, Circular 1136.

NADIMI, E., SØGAARD, H., BAK, T. \& OUDSHOORN, F. W. 2008. ZigBee-based wireless sensor networks for monitoring animal presence and pasture time in a strip of new grass. Computers and Electronics in Agriculture, 61, 79-87.

NIXON, S. W. 1995. Coastal marine eutrophication: a definition, social causes, and future concerns. Ophelia, 41, 199-219.

O'FlYNN, B., MARTINEZ, R., ClEARY, J., SLATER, C., REGAN, F., DIAMOND, D. \& MURPHY, H. SmartCoast: a wireless sensor network for water quality monitoring. 2007. Ieee, 815-816. 
O'FLYNN, B., REGAN, F., LAWLOR, A., WALLACE, J., TORRES, J. \& O'MATHUNA, C. 2010. Experiences and recommendations in deploying a real-time, water quality monitoring system. Measurement Science and Technology, 21, 124004.

PACIFICORP, K. H. P. 2002. Standard Operating Procedure for Water Quality Grab Sampling.

PAPOUTSA, C., HADJIMITSIS, D. G., THEMISTOCLEOUS, K., PERDIKOU, S., RETALIS, A. \& TOULIOS, L. Smart monitoring of water quality in Asprokremmos Dam in Paphos, Cyprus using satellite remote sensing and wireless sensor platform. 2010. 78310Q.

PARK, Y. \& HARMON, T. Soil Moisture, Salinity, and Nitrate Control for Soil and Groundwater Protection in Support of Wireless Sensor Networks and Optimal Irrigation Strategy. AGU Fall Meeting Abstracts, 2007. 1514.

PEREIRA, L. S., OWEIS, T. \& ZAIRI, A. 2002. Irrigation management under water scarcity. Agricultural Water Management, 57, 175-206.

PITMAN, M. \& LÄUCHLI, A. 2004. Global impact of salinity and agricultural ecosystems. Salinity: environment-plants-molecules, 3-20.

POLLARD, P. \& HUXHAM, M. 1998. The European Water Framework Directive: a new era in the management of aquatic ecosystem health? Aquatic Conservation: Marine and Freshwater Ecosystems, 8, 773792.

RAMANATHAN, N., BALZANO, L., ESTRIN, D., HANSEN, M., HARMON, T., JAY, J., KAISER, W. \& SUKHATME, G. Designing wireless sensor networks as a shared resource for sustainable development. International Conference on Information and Communication Technologies and Development, 2006., 2006. IEEE, 256-265.

RATÂKO, A., DIETRICH, H., PARK, Y., GONZALEZ-JIMENEZ, R., KIM, D., ASWIN, B., GOLDBERG, I., HARMON, T. \& JUDY, J. 2009. Micro- and Mini-nitrate Sensors for Monitoring of Soils, Groundwater and Aquatic Systems, UC Los Angeles: Center for Embedded Network Sensing, http://www.escholarship.org/uc/item/7td3g73w.

REGAN, F., LAWLOR, A., FLYNN, B. O., TORRES, J., MARTINEZ-CATALA, R., O'MATHUNA, C. \& WALLACE, J. A demonstration of wireless sensing for long term monitoring of water quality. 2009. IEEE, 819825.

REYNOLDS, K. A. 2003. Pharmaceuticals in drinking water supplies. Water Conditioning and Purification Magazine, 45.

RITCHIE, J. C., ZIMBA, P. V. \& EVERITT, J. H. 2003. Remote sensing techniques to assess water quality. Photogrammetric Engineering and Remote Sensing, 69, 695-704.

ROBERTSON, C., SMITH, G. \& TAMBURRI, M. 2009. Performance Demonstration Statement PMEL Map CO2/Battelle Seaology pCO2 Monitoring System. Alliance for Coastal technologies, [UMCES] CBL 10-092.

ROSEGRANT, M. W., CAI, X. \& CLINE, S. A. 2002. World water and food to 2025: Dealing with scarcity, Intl Food Policy Research Inst.

RUIZ-GARCIA, L., LUNADEI, L., BARREIRO, P. \& ROBLA, I. 2009. A review of wireless sensor technologies and applications in agriculture and food industry: state of the art and current trends. Sensors, 9, 4728-4750.

RUNDEL, P. W., GRAHAM, E. A., ALLEN, M. F., FISHER, J. C. \& HARMON, T. C. 2009. Environmental sensor networks in ecological research. New Phytologist, 182, 589-607.

SEDERS, L. A., SHEA, C. A., LEMMON, M. D., MAURICE, P. A. \& TALLEY, J. W. 2007. Lakenet: an integrated sensor network for environmental sensing in lakes. Environmental Engineering Science, 24, $183-191$.

SHRESTHA, S., KAZAMA, F. \& NEWHAM, L. 2008. A framework for estimating pollutant export coefficients from long-term in-stream water quality monitoring data. Environmental Modelling \& Software, 23, 182-194.

SMITH, V. H. \& SCHINDLER, D. W. 2009. Eutrophication science: where do we go from here? Trends in ecology \& evolution, 24, 201-207.

TEDESCHI, A. \& DELL'AQUILA, R. 2005. Effects of irrigation with saline waters, at different concentrations, on soil physical and chemical characteristics. Agricultural Water Management, 77, 308-322.

TONG, S. T. Y. \& CHEN, W. 2002. Modeling the relationship between land use and surface water quality. Journal of Environmental Management, 66, 377-393. 
TRUBILOWICZ, J., CAI, K. \& WEILER, M. 2009. Viability of motes for hydrological measurement. Water Resour. Res, 45, W00D22.

TYLER, A. N., SVAB, E., PRESTON, T., PRÉSING, M. \& KOVÁCS, W. A. 2006. Remote sensing of the water quality of shallow lakes: A mixture modelling approach to quantifying phytoplankton in water characterized by high-suspended sediment. International Journal of Remote Sensing, 27, 1521-1537.

UNEP, U. N. E. P. 1998. Best Management Practices for Agricultural Non-Point Sources of Pollution. Caribbean Environment Programme, United Nations Environment Programme.

UNESCO 2006. Global Hydrology and Water Resources. Water: a shared responsibility.

VALIELA, I., COSTA, J., FOREMAN, K., TEAL, J. M., HOWES, B. \& AUBREY, D. 1999. Transport of groundwater-borne nutrients from watersheds and their effects on coastal waters. Biodegradation, 10, 177-197.

VANLAUWE, B., WENDT, J., DIELS, J., TIAN, G., ISHIDA, F., KEATINGE, D. \& CARSKY, R. Combined application of organic matter and fertilizer. 2001. Soil Science Society of America Inc., 247-279.

VELLIDIS, G., TUCKER, M., PERRY, C., KVIEN, C. \& BEDNARZ, C. 2008. A real-time wireless smart sensor array for scheduling irrigation. Computers and Electronics in Agriculture, 61, 44-50.

VERHOEVEN, J. T. A., ARHEIMER, B., YIN, C. \& HEFTING, M. M. 2006. Regional and global concerns over wetlands and water quality. Trends in Ecology \& Evolution, 21, 96-103.

WANG, N., ZHANG, N. \& WANG, M. 2006. Wireless sensors in agriculture and food industry-Recent development and future perspective. Computers and Electronics in Agriculture, 50, 1-14.

WEBSTER, P. J. \& GROSSMAN, R. 2003. Forecasting river discharge into Bangladesh on short, medium and long time scales. Climate Forecasting Applications in Bangladesh, January.

ZACHARIAS, S., BOGENA, H., SAMANIEGO, L., MAUDER, M., FUß, R., PÜTZ, T., FRENZEL, M., SCHWANK, M., BAESSLER, C. \& BUTTERBACH-BAHL, K. 2011. A network of terrestrial environmental observatories in Germany. Vadose Zone Journal, 10, 955-973.

ZEKTSER, I. S. \& LORNE, E. 2004. Groundwater resources of the world: and their use. IHP Series on groundwater.

ZENNARO, M., FLOROS, A., DOGAN, G., SUN, T., CAO, Z., HUANG, C., BAHADER, M., NTAREME, H. \& BAGULA, A. On the Design of a Water Quality Wireless Sensor Network (WQWSN): An Application to Water Quality Monitoring in Malawi. 2009. IEEE, 330-336.

ZHU, X., LI, D., HE, D., WANG, J., MA, D. \& LI, F. 2010. A remote wireless system for water quality online monitoring in intensive fish culture. Computers and Electronics in Agriculture, 71, Supplement 1, S3-S9.

ZHUIYKOV, S. 2007. Electrochemistry of zirconia gas sensors, CRC Press.

ZHUIYKOV, S. 2012. Solid-state sensors monitoring parameters of water quality for the next generation of wireless sensor networks. Sensors and Actuators B: Chemical, 161, 1-20.

ZIA, H., HARRIS, N. R. \& MERRETT, G. V. 2013. Collaborative Catchment-Scale Water Quality Management using Integrated Wireless Sensor Networks. EGU General Assembly 2013. Vienna, Austria: Geophysical Research Abstracts. 